\title{
Herpes zoster ophthalmicus in a 1-year-old child
}

\author{
Zaid Makzal, ${ }^{1}$ Martin Edwards ${ }^{2}$
}

Department of Paediatrics, University Hospital of Wales, Cardiff, UK

${ }^{2}$ Department of Paediatrics, University Hospital of Wales, Cardiff, UK

Correspondence to

Dr Zaid Makzal,

makzal@hotmail.com

Accepted 10 October 2017

\section{Q crossMark}

To cite: Makzal Z,

Edwards M. BMJ Case Rep Published Online First:

[please include Day Month Year]. doi:10.1136/bcr-2017222112

\section{DESCRIPTION}

A girl aged 15 months presented with a 2-day history of fatigue and fever, along with a vesicular rash over her right eye and forehead (see figure 1).

Swabs were sent for PCR and were positive for varicella zoster DNA, and a working diagnosis of herpes zoster ophthalmicus was made. There was no history of varicella zoster infection, although there was suggestion that there had been in utero exposure. She was treated with intravenous acyclovir for 48 hours until ophthalmology review confirmed that there was no ocular involvement. She was then discharged to complete a further 7 days of oral and topical treatment. Follow-up 3 weeks later showed complete resolution of the rash.

In general, herpes zoster is uncommon in individuals younger than 10 years of age and rare in infants. ${ }^{1}$ Herpes zoster infections are more common and often more dangerous in immunocompromised patients, with the potential for life-threatening complications. Prompt antiviral therapy should be started in all immunocompromised patients. ${ }^{2}$

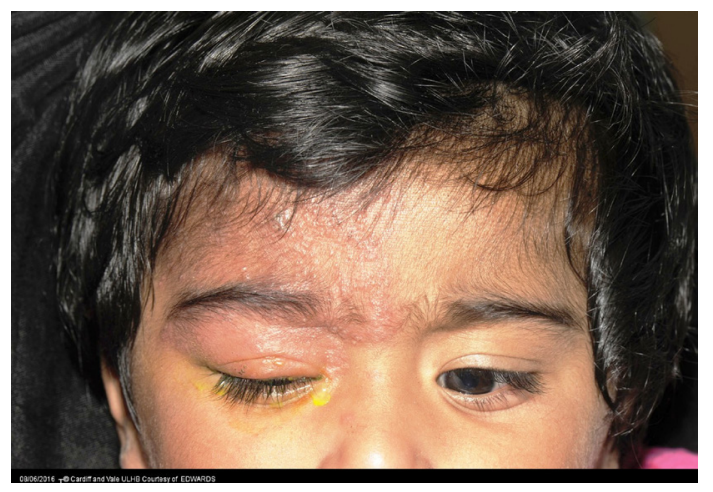

Figure 1 Herpes zoster ophthalmicus affecting the right eye.

\section{Learning points}

- Urgent treatment with acyclovir and ophthalmology review are needed for any child presenting with herpes zoster affecting the eye.

- Herpes zoster infection in immunocompromised children needs prompt recognition and treatment.

- $1.2 \%$ of babies who were exposed in utero to varicella in the second or third trimester develop shingles in infancy or childhood. ${ }^{3}$

Herpes zoster ophthalmicus has a good prognosis in healthy children; however, known sequelae include keratitis and anterior uveitis.

Contributors Both authors were involved in the management of this patient and subsequent acquisition of the images used. ZM drafted the article and ME revised it critically for important intellectual content. Both authors approved the final version published. Both authors agree to be accountable for the article and to ensure that all questions regarding the accuracy or integrity of the article are investigated and resolved.

Competing interests None declared.

Patient consent Guardian consent obtained.

Provenance and peer review Not commissioned; externally peer reviewed.

(c) BMJ Publishing Group Ltd (unless otherwise stated in the text of the article) 2017. All rights reserved. No commercial use is permitted unless otherwise expressly granted.

\section{REFERENCES}

1 Kawai K, Gebremeskel BG, Acosta CJ. Systematic review of incidence and complications of herpes zoster: towards a global perspective. BMJ Open 2014;4:e004833.

2 Ahmed AM, Brantley JS, Madkan V, et al. Managing herpes zoster in immunocompromised patients. Herpes 2007;14:32-6.

3 Leung AK. In: Herpes Zoster. Leung AK, ed. Common problems in ambulatory pediatrics: specific clinical problems. . New York:Nova Science Publishers, 2011:1. 285-9.

Copyright 2017 BMJ Publishing Group. All rights reserved. For permission to reuse any of this content visit http://group.bmj.com/group/rights-licensing/permissions.

BMJ Case Report Fellows may re-use this article for personal use and teaching without any further permission.

Become a Fellow of BMJ Case Reports today and you can:

- Submit as many cases as you like

- Enjoy fast sympathetic peer review and rapid publication of accepted articles

- Access all the published articles

- Re-use any of the published material for personal use and teaching without further permission

For information on Institutional Fellowships contact consortiasales@bmjgroup.com

Visit casereports.bmj.com for more articles like this and to become a Fellow 